\title{
Piper Essential Oils Inhibit Rhizopus oryzae Growth, Biofilm Formation, and Rhizopuspepsin Activity
}

\author{
Catia A. Almeida, ${ }^{1}$ Mariana M. B. Azevedo $\left({ }^{1},{ }^{1}\right.$ Francisco C. M. Chaves, ${ }^{2}$ \\ Marcelo Roseo de Oliveira, ${ }^{2}$ Igor A. Rodrigues $\left(\mathbb{D},{ }^{3}\right.$ Humberto R. Bizzo, ${ }^{4}$ Paola E. Gama, ${ }^{4}$ \\ Daniela S. Alviano, ${ }^{1}$ and Celuta S. Alviano ${ }^{1}$ \\ ${ }^{1}$ Department of General Microbiology, Institute of Microbiology Paulo de Góes, Federal University of Rio de Janeiro \\ (IMPG-UFRJ), CCS Ilha do Fundão, 21941-590 Rio de Janeiro, RJ, Brazil \\ ${ }^{2}$ EMBRAPA Western Amazon, Rodovia AM $10 \mathrm{~km}$ 29, 69010-970 Manaus, AM, Brazil \\ ${ }^{3}$ School of Farmacy, Department of Natural Products and Food, Federal University of Rio de Janeiro, CCS Ilha do Fundão, \\ 21941-902 Rio de Janeiro, RJ, Brazil \\ ${ }^{4}$ EMBRAPA Food Technology, Avenida das Américas 29501, 23020-470 Rio de Janeiro, RJ, Brazil
}

Correspondence should be addressed to Mariana M. B. Azevedo; marimbarros@gmail.com

Received 22 March 2018; Revised 29 May 2018; Accepted 11 June 2018; Published 5 July 2018

Academic Editor: Mario Dell'Agli

Copyright (c) 2018 Catia A. Almeida et al. This is an open access article distributed under the Creative Commons Attribution License, which permits unrestricted use, distribution, and reproduction in any medium, provided the original work is properly cited.

\begin{abstract}
Piper is the largest genus of the Piperaceae family. The species of this genus have diverse biological activities and are used in pharmacopeia throughout the world. They are also used in folk medicine for treatment of many diseases in several countries including Brazil, China, India, Jamaica, and Mexico. In Brazil, Piper species are distributed throughout the national territory, making this genus a good candidate for biological activity screening. During our studies with Piper essential oils, we evaluated its activity against Rhizopus oryzae, the main agent of mucormycosis. The main compounds of seven Piper essential oils analyzed were Piper callosum-safrole (53.8\%), P. aduncum-dillapiole (76.0\%), P. hispidinervum-safrole (91.4\%), P. marginatum-propiopiperone (13.2\%), P. hispidum- $\gamma$-terpinene (30.9\%), P. tuberculatum-(E)-caryophyllene (30.1\%), and Piper sp.-linalool (14.6\%). The minimum inhibitory concentration of Piper essential oils against $R$. oryzae ranged from 78.12 to $>1250 \mu \mathrm{g} / \mathrm{mL}$. The best result of total inhibition of biofilm formation was obtained with Piper sp. starting from $4.88 \mu \mathrm{g} / \mathrm{mL}$. Considering the bioactive potential of EOs against planktonic cells and biofilm formation of $R$. oryzae could be of great interest for development of antimicrobials for therapeutic use in treatment of fungal infection.
\end{abstract}

\section{Introduction}

Piper is the largest genus of the Piperaceae family. The species of this genus have diverse biological activities and are used in pharmacopeia throughout the world. They are also used in folk medicine for treatment of many diseases in several countries including Brazil, China, India, Jamaica, and Mexico. In Brazil, Piper species are distributed throughout the national territory. Among the aromatic flora of the Amazon region, there are more than a dozen species that provide essential oils that are used by the population for therapeutic purposes. The tea of the decoction of Piper hispidum leaves is useful for the treatment of malaria. Piper marginatum is used as a tonic, carminative, stimulant, diuretic, and sudorific agent against stomach, liver and gallbladder pain, toothaches, and snake and insect bites [1]. Regasini et al. [2] related trypanocidal activity of the Piper tuberculatum extract.

Zygomycosis, also referred to as phycomycosis or mucormycosis, is an aggressive and rapidly progressive infection that primarily occurs in immunocompromised patients. Members of the genera Rhizopus, Mucor, and Absidia are the organisms most commonly isolated from patients with zygomycosis. Rhizomucor, Cunninghamella, 
TABle 1: Deposit number and deposit location of plant material.

\begin{tabular}{|c|c|c|c|}
\hline Plant material & Deposit number & Deposit location & Name of herbarium \\
\hline Piper aduncum & 10,480 & INPA $^{1}$ & INPA herbarium \\
\hline Piper tuberculatum & 6,797 & IFAM $^{2}$ & EAFM herbarium \\
\hline Piper hispidum & 6,796 & IFAM & EAFM herbarium \\
\hline Piper marginatum & 6,798 & IFAM & EAFM herbarium \\
\hline Piper callosum & 6,794 & IFAM & EAFM herbarium \\
\hline Piper hispidinervum & & IFAM & EAFM herbarium \\
\hline Piper sp. & & IFAM & EAFM herbarium \\
\hline
\end{tabular}

${ }^{1}$ National Institute of Amazonas Research; ${ }^{2}$ Federal Institute of Amazonas.

Apophysomyces, and Saksenaea are other zygomycetes that have been implicated in human diseases. Amphotericin B, as well as its lipid formulation, has been essential for treatment for several decades [3].

The purpose of the present work was to evaluate the antiRhizopus oryzae activity of Piper aduncum, P. hispidinervum, $P$. callosum, $P$. hispidum, $P$. tuberculatum, $P$. marginatum, and Piper sp. essential oil of leaves.

\section{Materials and Methods}

2.1. Plant Material and Essential Oil Extraction. Plant material was obtained from EMBRAPA Experimental Farm, Amazonas, Brazil. A voucher of each specimen was deposited at Federal Agrotechnical School of Machado Herbarium (Table 1). Leaves of Piper species were collected between 8 and 9 a.m., dried at room temperature, and coarsely ground into powder just before distillation. The oil was obtained by hydrodistillation in a modified Clevenger apparatus for $5 \mathrm{~h} \mathrm{[4]}$.

2.2. Essential Oil Analyses. Sample of each Piper essential oil was analyzed in an Agilent $6890 \mathrm{~N}$ gas chromatograph fitted with a 5\% diphenyl-95\% dimethylpolysiloxane capillary column (DB-5MS, $30 \mathrm{~m} \times 0.25 \mathrm{~mm} \times 0.25 \mu \mathrm{m}$ ). The results were compared to data from the literature [5].

2.3. Antifungal Activity Assay. The antifungal activity of Piper essential oils was evaluated against $R$. oryzae (UCP1506). The strain used belongs to the culture collection of the "Universidade Católica de Pernambuco," located in the Nucleus of Research in Environmental Sciences, Catholic University of Pernambuco, Brazil, NPCIAMB/UNICAP. The culture collection is registered in the WFCC.

The microdilution broth method was used according to CLSI reference document M38-A [6] for filamentous fungi. Briefly, the cells were grown in RPMI-MOPS ( $\mathrm{pH}$ 7.2) for $18 \mathrm{~h}$ at $30^{\circ} \mathrm{C}$ in the presence of different concentrations (1.22 to $1250 \mu \mathrm{g} / \mathrm{mL}$ ) of each essential oil. Positive and negative growth controls were performed. Amphotericin B (Sigma) was used as a reference drug, and stock solution was made at $20 \mathrm{mg} / \mathrm{mL}$ in sterile distilled water. All experiments were performed in duplicate and repeated twice.

In order to evaluate the fungicide/fungistatic properties of Piper essential oils, a $10 \mu \mathrm{L}$ aliquot was collected from the inhibited cultures and dropped on the surface of potato dextrose agar. The absence or presence of growth in the solid medium was evaluated after $48 \mathrm{~h}$ incubation period at $30^{\circ} \mathrm{C}$.
2.4. Biofilm Formation. The influence of Piper essential oils on biofilm formation was determined as described by Singh et al. [7]. Briefly, spores of $R$. oryzae were put in 96-well microtiter plate at $5 \times 10^{4}$ cells per $\mathrm{mL}$ in RPMI and treated with twofold serial dilution of each Piper essential oil. After incubation for $18 \mathrm{~h}$ at $30^{\circ} \mathrm{C}$, the culture media was removed and the wells were washed twice with PBS 0.01 M and pH 7.2. Biofilms were stained with $200 \mu \mathrm{L}$ of $0.1 \%$ safranin for $5 \mathrm{~min}$. Then, the supernatants were removed, and the wells were washed twice with PBS. Finally, $200 \mu \mathrm{L}$ of $30 \%$ glacial acetic acid was added to the microplates in order to elute safranine from the matrix. Biofilm formation was estimated by spectrophotometry (SpectraMax M5) at $490 \mathrm{~nm}$.

2.5. Red Blood Cell Lysis Assay. The hemolytic activity was evaluated by Franca Rodrigues et al. [8] by mixing $80 \mu \mathrm{L}$ of a $5 \%$ suspension of fresh human red blood cells $\left(\mathrm{O}^{+}\right)$in $\mathrm{PBS}$ with $20 \mu \mathrm{L}$ of different concentrations of Piper sp. essential oil and incubating at $37^{\circ} \mathrm{C}$ for $1 \mathrm{~h}$. The reaction was slowed by adding $200 \mu \mathrm{L}$ of PBS, and the suspension was centrifuged $(1000 \mathrm{~g}$ for $10 \mathrm{~min})$. The supernatant was transferred to a 96-well plate, and cell lysis was quantified by spectrophotometrical measurement of absorbance at $540 \mathrm{~nm}$, as previously described. The maximal lysis and blank control were obtained by replacing the extract sample with an equal volume of PBS or distilled water, respectively.

2.6. Rhizopuspepsin Inhibition. In order to evaluate a possible mode of action of the Piper essential oils, the inhibition of rhizopuspepsin (Sigma) activity was determined as previously described by Buroker-Kilgore and Wang with some modifications [9]. First, $59 \mu \mathrm{L}$ of the rhizopuspepsin solution was mixed with $1 \mu \mathrm{L}$ inhibitor, $20 \mu \mathrm{L}$ BSA $(1 \mathrm{mg} / \mathrm{mL})$, and $20 \mu \mathrm{L}$ buffer ( $\mathrm{pH} 3.0$ ). After $1 \mathrm{~h}$ incubation at $37^{\circ} \mathrm{C}, 100 \mu \mathrm{L}$ of Bradford solution (0.025\% Coomassie Blue G-250, 11.75\% ethanol, and $21.25 \%$ phosphoric acid) previously diluted $(1: 1)$ was added. Negative control was performed by adding the substrate immediately after the incubation period. Finally, the plate was read on a spectrophotometer (SpectraMax M5) at $595 \mathrm{~nm}$. One unit of enzyme activity was defined as the total enzyme that causes an increase of 0.001 in unit of absorbance under the conditions of the standard assay. The inhibitors tested were Piper essential oils $(48 \mu \mathrm{g} / \mathrm{mL}$ ) and $10 \mathrm{mM}$ Pepstatin A (standard inhibitor). 
TABLe 2: Main components from Piper spp. essential oils.

\begin{tabular}{|c|c|c|c|c|c|c|c|c|c|c|}
\hline \multirow[b]{2}{*}{ Peak } & \multirow[b]{2}{*}{$\begin{array}{l}\text { LRI } \\
\text { calc }\end{array}$} & \multirow[b]{2}{*}{$\begin{array}{l}\text { LRI } \\
\text { lit }\end{array}$} & \multirow[b]{2}{*}{ Identification } & \multicolumn{7}{|c|}{ Area (\%) } \\
\hline & & & & $\begin{array}{c}P . \\
\text { callosum }\end{array}$ & $\begin{array}{c}P . \\
\text { aduncum }\end{array}$ & $\begin{array}{c}P . \\
\text { hispidinervum }\end{array}$ & $\begin{array}{c}P . \\
\text { marginatum }\end{array}$ & $\begin{array}{c}P . \\
\text { hispidum }\end{array}$ & $\begin{array}{c}P . \\
\text { tuberculatum }\end{array}$ & $\begin{array}{c}\text { Piper } \\
\text { sp. }\end{array}$ \\
\hline 1 & 924 & 924 & $\alpha$-Thujene & 0.1 & & & 0.1 & 0.1 & & \\
\hline 2 & 931 & 932 & $\alpha$-Pinene & 12.2 & 1.5 & 0.1 & 2.0 & 1.3 & 9.4 & \\
\hline 3 & 946 & 946 & Canphene & 0.4 & 0.1 & & & 0.1 & & \\
\hline 4 & 971 & 969 & Sabinene & 3.0 & & & 0.1 & & & \\
\hline 5 & 975 & 974 & $\beta$-Pinene & 7.7 & 3.5 & & 1.5 & 1.1 & 15.0 & \\
\hline 6 & 985 & 981 & $\begin{array}{l}\text { 6-Methyl-5-hepten-2- } \\
\text { one }\end{array}$ & & & & & 0.6 & & \\
\hline 7 & 989 & 990 & Myrcene & 0.6 & & 0.1 & 1.3 & 1.2 & & \\
\hline 8 & 1004 & 1002 & $\alpha$-Phellandrene & 0.1 & & & 1.5 & 0.5 & & \\
\hline 9 & 1009 & 1008 & $\delta$-3-Carene & & & 0.2 & 11.3 & 0.4 & & \\
\hline 10 & 1014 & 1014 & $\alpha$-Terpinene & 0.7 & & & 0.2 & 14.4 & & \\
\hline 11 & 1022 & 1022 & $p$-Cimene & 0.3 & 0.3 & 0.3 & 0.3 & 12.1 & & \\
\hline 12 & 1025 & 1024 & Limonene & 0.7 & 0.4 & 0.2 & & & 1.6 & \\
\hline 13 & 1026 & 1025 & $\beta$-Phellandrene & & & & 1.0 & 1.4 & & \\
\hline 14 & 1028 & 1026 & 1,8-Cineole & 3.7 & & & & & & \\
\hline 15 & 1034 & 1032 & $(Z)-\beta$-Ocimene & & 0.4 & 0.3 & 6.0 & & & \\
\hline 16 & 1044 & 1044 & (E)- $\beta$-Ocimene & & 0.8 & 0.7 & 8.3 & & & \\
\hline 17 & 1055 & 1054 & $\gamma$-Terpinene & 1.8 & & & 0.3 & 30.9 & & \\
\hline 18 & 1085 & 1086 & Terpinolene & 0.5 & & 1.2 & 0.3 & 7.3 & & \\
\hline 19 & 1098 & 1098 & Linalool & 0.3 & 0.2 & & 1.1 & & & 14.6 \\
\hline 20 & 1134 & 1135 & trans-Pinocarveol & & 0.2 & & & & & \\
\hline 21 & 1152 & 1155 & Isoborneol & 0.1 & & & & & & \\
\hline 22 & 1173 & 1174 & Terpinen-4-ol & 0.7 & & & & 1.0 & & \\
\hline 23 & 1182 & 1179 & p-8-Cymenol & & & 1.0 & & & & \\
\hline 24 & 1187 & 1186 & $\alpha$-Terpineol & 0.5 & 0.1 & & & & & \\
\hline 25 & 1193 & 1194 & Myrtenol & & 0.1 & & & & & \\
\hline 26 & 1314 & 1285 & Safrole & 53.8 & & 91.4 & 4.6 & & & \\
\hline 27 & 1332 & 1335 & $\delta$-Elemene & & & & 0.3 & & & \\
\hline 28 & 1370 & 1374 & $\alpha$-Copaene & 0.5 & 0.5 & & 4.8 & 0.5 & 1.3 & \\
\hline 29 & 1379 & 1387 & $\beta$-Bourbonene & & & & 0.9 & & & \\
\hline 30 & 1385 & 1387 & $\beta$-Cubebene & & & & 0.3 & & & \\
\hline 31 & 1387 & 1389 & $\beta$-Elemene & & & & 0.6 & & 3.0 & \\
\hline 32 & 1402 & 1403 & Methyl eugenol & 7.6 & & & 5.4 & & & \\
\hline 33 & 1413 & 1417 & (E)-Caryophyllene & 0.7 & 6.0 & 0.3 & 6.3 & 5.3 & 30.1 & 14.4 \\
\hline 34 & 1423 & 1430 & $\beta$-Copaene & & & & 0.3 & & 2.8 & \\
\hline 35 & 1438 & 1439 & Aromadendrene & & & & & 1.4 & & \\
\hline 36 & 1447 & 1452 & $\alpha$-Humulene & 0.1 & 0.9 & & 0.7 & 0.4 & & 7.1 \\
\hline 37 & 1450 & - & n.i. & & & & 0.3 & & & \\
\hline 38 & 1456 & 1457 & Croweacin & & & & 0.9 & & & \\
\hline 39 & 1468 & 1471 & $\begin{array}{l}\text { 4,5-Di-epi- } \\
\text { aristolochene }\end{array}$ & & & & & 0.3 & & \\
\hline 40 & 1475 & 1476 & $\beta$-Chamigrene & & & & & 1.6 & & \\
\hline 41 & 1480 & 1489 & $\beta$-Selinene & & & & 1.7 & 8.1 & 2.6 & 5.5 \\
\hline 42 & 1489 & 1498 & $\alpha$-Selinene & & & & & 9.0 & 1.7 & 5.0 \\
\hline 43 & 1499 & 1500 & Epizonarene & & & & & 0.1 & & \\
\hline 44 & 1471 & 1478 & $\gamma$-Muurolene & 0.4 & & & & & & 1.6 \\
\hline 45 & 1474 & 1484 & Germacrene D & 1.0 & 0.6 & & 2.9 & & & \\
\hline 46 & 1488 & 1493 & Epi-cubebol & & 0.4 & & & & & \\
\hline 47 & 1490 & 1494 & Bicyclogermacrene & & 0.5 & 1.0 & 3.9 & & & \\
\hline 48 & 1491 & 1494 & Sarisan & & & 0.3 & & & & \\
\hline 49 & 1495 & 1500 & Pentadecane & & 0.3 & 0.2 & & & & \\
\hline 50 & 1498 & 1505 & Germacrene A & & & & 0.2 & & & \\
\hline 51 & 1500 & 1500 & $\alpha$-Muurolene & & & & & 0.2 & & \\
\hline 52 & 1500 & 1506 & $\beta$-Bisabolene & & & & & & 9.1 & \\
\hline 53 & 1509 & 1514 & Cubebol & & 0.8 & & & & & \\
\hline 54 & 1510 & - & n.i. & & & & 1.6 & & & \\
\hline 55 & 1518 & 1517 & Myristicin & & 2.4 & 2.0 & & & & \\
\hline 56 & 1513 & 1513 & $\gamma$-Cadinene & & & & & 0.4 & & 3.5 \\
\hline
\end{tabular}


TABLE 2: Continued.

\begin{tabular}{|c|c|c|c|c|c|c|c|c|c|c|}
\hline \multirow[b]{2}{*}{ Peak } & \multirow[b]{2}{*}{$\begin{array}{l}\text { LRI } \\
\text { calc }\end{array}$} & \multirow[b]{2}{*}{$\begin{array}{l}\text { LRI } \\
\text { lit }\end{array}$} & \multirow[b]{2}{*}{ Identification } & \multicolumn{7}{|c|}{ Area (\%) } \\
\hline & & & & $\begin{array}{c}P . \\
\text { callosum }\end{array}$ & $\begin{array}{c}P . \\
\text { aduncum }\end{array}$ & $\begin{array}{c}P . \\
\text { hispidinervum }\end{array}$ & $\begin{array}{c}P . \\
\text { marginatum }\end{array}$ & $\begin{array}{c}P . \\
\text { hispidum }\end{array}$ & $\begin{array}{c}P . \\
\text { tuberculatum }\end{array}$ & $\begin{array}{l}\text { Piper } \\
\text { sp. }\end{array}$ \\
\hline 57 & 1516 & 1520 & 7-epi- $\alpha$-Selinene & & & & & 0.2 & & \\
\hline 58 & 1501 & 1511 & $\delta$-Amorphene & & 0.3 & & & & & \\
\hline 59 & 1518 & 1522 & $\delta$-Cadinene & 0.4 & & & 0.8 & 1.1 & & 1.2 \\
\hline 60 & 1530 & 1545 & Propiopiperone & & & & 13.2 & & & 1.2 \\
\hline 61 & 1544 & 1548 & Elemol & & & & 1.1 & & & \\
\hline 62 & 1554 & 1555 & Elemicin & 1.4 & & & 2.7 & & & \\
\hline 63 & 1559 & 1561 & (E)-Nerolidol & & 0.5 & & 1.0 & & 6.5 & 13.8 \\
\hline 64 & 1571 & 1577 & Spathulenol & & 0.5 & 0.7 & 4.1 & & 2.2 & 2.5 \\
\hline 65 & 1576 & 1582 & Caryophyllene oxide & & 1.5 & & 1.8 & & 13.3 & 10.1 \\
\hline 66 & 1580 & 1601 & $\alpha$-Cedrol & & & & & & & 3.1 \\
\hline 67 & 1582 & 1590 & Globulol & & & & & 1.2 & & \\
\hline 68 & 1584 & 1592 & Viridiflorol & & 1.2 & & & & & \\
\hline 69 & 1593 & 1624 & Selina-6-en-4-ol & & & & & & & 7.3 \\
\hline 70 & 1606 & - & n.i. & & & & & 0.6 & & \\
\hline 71 & 1618 & - & n.i. & & & & & 0.1 & & \\
\hline 72 & 1625 & 1620 & Dillapiole & & 76.0 & & & & & \\
\hline 73 & 1625 & 1627 & 1-epi-Cubenol & & & & 0.9 & & & \\
\hline 74 & 1631 & 1642 & $\begin{array}{l}\text { 2-Hydroxy-3, } \\
\text { 4-methylenedioxy } \\
\text { propiophenone }\end{array}$ & & & & 1.0 & & & \\
\hline 75 & 1637 & 1638 & epi- $\alpha$-Cadinol & & & & & 0.5 & & \\
\hline 76 & 1640 & 1644 & $\alpha$-Muurolol & 0.2 & & & & & & \\
\hline 77 & 1648 & 1649 & $\beta$-Eudesmol & 0.2 & & & 0.9 & & & \\
\hline 78 & 1651 & 1658 & Selin-11-en- $4 \alpha$-ol & & & & & 2.0 & & \\
\hline 79 & 1652 & 1652 & $\alpha$-cadinol & & & & 1.2 & & 1.5 & 3.0 \\
\hline 80 & 1655 & 1658 & neo-Intermedeol & & & & 0.5 & & & \\
\hline
\end{tabular}

2.7. Antioxidant Activity of Piper spp. Essential Oils. The antioxidant activity was evaluated qualitatively $[10,11]$ by application of $0.5 \mu \mathrm{L}$ of each essential oil and 7-hydroxycalamenene (as standard) on a plate of silica gel $60 \mathrm{~F}_{254}$ and eluted with hexane-ethyl acetate $(9: 1)$. The plates were treated with a $0.2 \%$ methanolic solution of DPPH and read just after spraying and after $45 \mathrm{~min}$.

\section{Results and Discussion}

The average oil yield obtained was $0.65 \%$ (dry wt.). The compounds present in the essential oils from Piper species used are shown in Table 2. Quantitative and/or qualitative variations were observed among samples of Piper.

The essential oils of $P$. aduncum, $P$. hispidinervum, P. callosum, P. marginatum, $P$. hispidum, $P$. tuberculatum, and Piper sp. were analyzed by GC and GC-MS, and the percentage of identified components is given in Table 2 .

The major compounds of $P$. aduncum and P. hispidinervum were identified as dillapiole (76\%) and safrole (91.4\%), respectively. In the oil of $P$. callosum, the main components were safrole (53.8\%) and $\alpha$-pinene $(12.2 \%)$. Major components of $P$. marginatum were propiopiperone $(13.2 \%)$ and $\delta$-3-carene (11.3\%). P. hispidum presented the terpinene isoforms $\gamma$-terpinene $(30.9 \%)$ and $\alpha$-terpinene $(14.4 \%)$ as main compounds. $\beta$-Pinene $(15 \%)$ and caryophyllene oxide $(13.3 \%)$ were the major constituents of $P$. tuberculatum, while the sesquiterpenes linalool (14.6\%) and nerolidol (13.8\%) were identified in the Piper sp. oil.
Dillapiole has been described as acaricidal (Rhipicephalus (Boophilus) microplus), larvicidal and insecticidal (Anopheles marajoara, Aedes aegypti, and Solenopsis saevissima), and antifungal (Aspergillus fumigatus) agent. Safrole demonstrated antileishmanial (L. major, L. mexicana, L. braziliensis, and L. donovani) activity. Propiopiperone exhibited antifungal activity against Cladosporium cladosporioides and C. sphareospermum. Oyedemi et al. [12] showed the activity of $\gamma$-terpinene against Proteus vulgaris and Escherichia coli. Our group previously described [13] the activity of (+)- $\beta$-pinene against Cryptococcus neoformans and Candida albicans. Other promising activity described by our group [14] was linalool-rich essential oil of Lippia alba against two dermatophytes Trichophyton rubrum and Epidermophyton floccosum [12-21].

The results of the MIC assay of Piper essential oils and amphotericin B against $R$. oryzae are shown in Table 3.

Sartoratto et al. [22] considered MIC values between 50 and $500 \mu \mathrm{g} / \mathrm{mL}$ as strong activity, MIC values between 600 and $1500 \mu \mathrm{g} / \mathrm{mL}$ as moderate activity, and above $1500 \mu \mathrm{g} / \mathrm{mL}$ as weak activity [21]. According to this classification, it could be stated that Piper sp., P. marginatum, and P. hispidum essential oils present high activity, $P$. tuberculatum and $P$. hispidinervum present moderate activity, and $P$. aduncum and $P$. callosum against $R$. oryzae planktonic cells present weak activity.

Based on previous MIC results, the essential oils tested on biofilm formation were $P$. hispidum, $P$. marginatum, and P. tuberculatum; Piper sp. Rhizopus oryzae biofilm formation in the presence of each Piper essential oil was inhibited in 
Table 3: MIC values $(\mu \mathrm{g} / \mathrm{ml})$ of Piper essential oils and amphotericin B against $R$. oryzae.

\begin{tabular}{lcc}
\hline Essential oil & MIC & MFC \\
\hline Piper aduncum & $>1250$ & ND \\
Piper hispidinervum & 1250 & ND \\
Piper callosum & $>1250$ & ND \\
Piper marginatum & 156.25 & $>1250$ \\
Piper hispidum & 312.5 & $>1250$ \\
Piper tuberculatum & 625 & $>1250$ \\
Piper sp. & 78.12 & $>156.5$ \\
Amphotericin B & 0.98 & 1.95 \\
Posaconazole & 1.56 & 1.56 \\
\hline
\end{tabular}

MIC: minimal inhibition concentration; MFC: minimal fungicide concentration; ND: not determined.

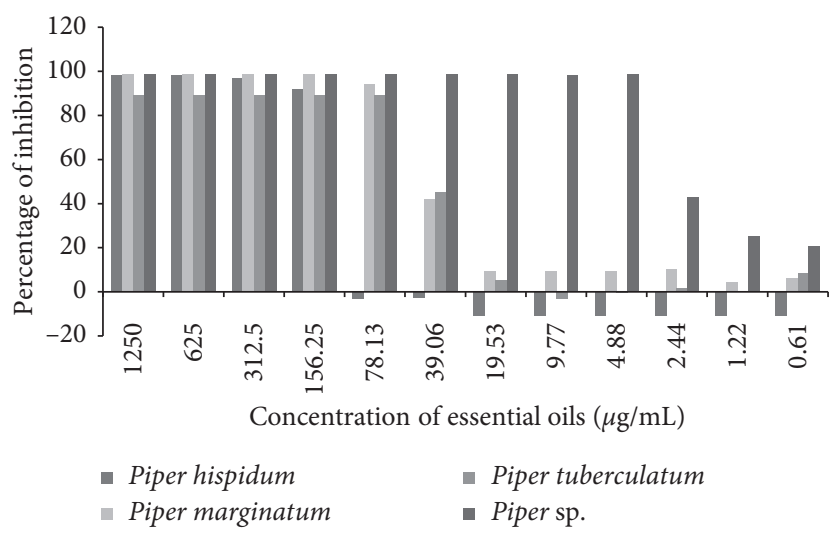

Figure 1: Effect of Piper essential oils against R. oryzae biofilm formation. The plates were incubated at $30^{\circ} \mathrm{C}$ for $18 \mathrm{~h}$.

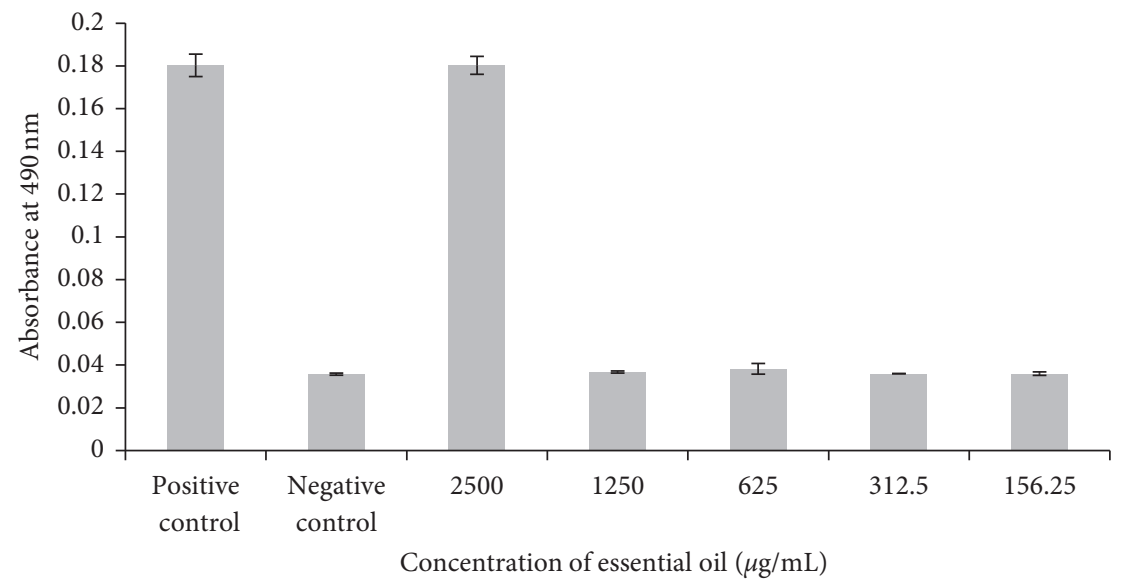

FIgURE 2: Hemolytic assay after treatment with various concentrations of Piper sp. essential oil.

lower concentration than MIC for all species tested (Figure 1).

In their natural environments, most of bacteria and fungi change from a planktonic to a sessile state forming the socalled biofilms. Biofilms are sessile microbial and fungal communities that are strongly attached to surfaces and to each other; in such phase, they are protected by a polymeric extracellular matrix (ECM), constituted primarily of polysaccharides. According to Singh et al. [7], the major compounds of biofilm matrix are GlcN and GlcNAc. The cell wall of zygomicetes is also mainly formed by $\mathrm{GlcN}$ and GlcNAc polymer constituents of chitosan and chitin, respectively. Then, our results on MIC and inhibition of biofilm formation could be associated with each other. The essential oil of Piper sp. showed the most active agent against the two cell forms, planktonic and biofilm [7, 23]. 


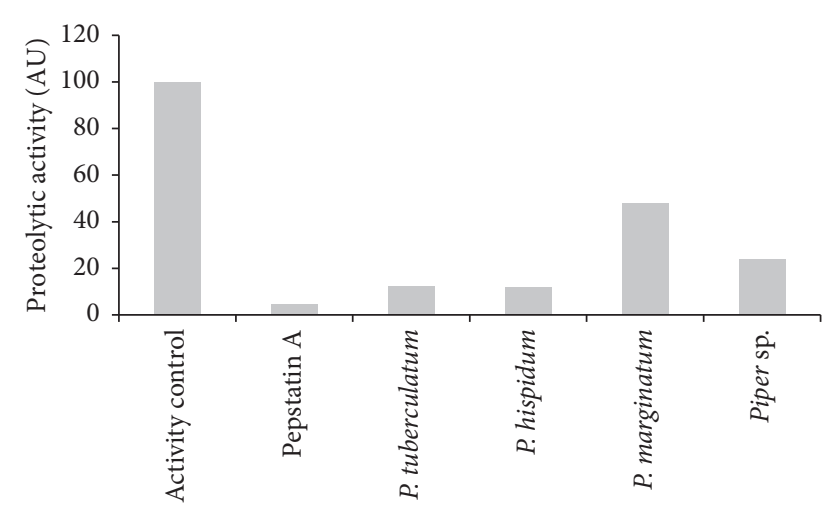

Figure 3: Proteolytic activity of rhizopuspepsin after overnight treatment with $48 \mu \mathrm{g} / \mathrm{ml}$ of Piper essential oils. The plates were incubated at $37^{\circ} \mathrm{C}$.

Piper sp. essential oil was the most active agent against planktonic cells and biofilm formation (78.12 and $4.88 \mu \mathrm{g} / \mathrm{mL}$, resp.). However, this essential oil displayed hemolytic activity (Figure 2) at higher concentration $(2500 \mu \mathrm{g} / \mathrm{mL})$, making it a promising antifungal candidate.

Other important mechanism of action is the inhibition of rhizopuspepsin and/or saps, a class of enzymes secreted for R. oryzae and other Rhizopus species [24]. The results in Figure 3 showed inhibition of proteolytic activity of rhizopuspepsin when Piper essential oils were used, mainly P. hispidum and P. tuberculatum which inhibited $11.8 \%$ and $12.05 \%$ of enzymatic activity, respectively.

The antioxidant activity was evaluated after TLC of Piper essential oils. It was not possible to identify regions containing substances with activity even after $45 \mathrm{~min}$ of application of DPPH. Terpenes are the most significant class of compounds present in essential oils. Among them, several monoterpene hydrocarbons, oxygenated monoterpenes, and sesquiterpenes are often reported as weak antioxidant agents [25]. However, due to the complexity of essential oils' composition, some antioxidant activity was expected. Thus, further investigation will be necessary in order to evaluate other antioxidant methods.

\section{Conclusion}

This study showed the promising anti-Rhizopus oryzae activity of Piper tuberculatum, P. hispidum, and Piper sp. against planktonic cells, biofilm formation, and rhizopuspepsin which makes these essential oils useful in formulating strategies to limit the growth of $R$. oryzae.

\section{Conflicts of Interest}

The authors declare that they have no conflicts of interest concerning this article.

\section{Acknowledgments}

This study was supported by the Brazilian agencies Rio de Janeiro State Research Foundation (FAPERJ), Coordination for Improvement of Higher Education Personnel (CAPES), and National Council for Scientific and Technological Development (CNPq).

\section{References}

[1] R. Takeara, R. Gonçalves, V. F. dos Santos Ayres, and A. C. Guimarães, "Biological properties of essential oils from the Piper species of Brazil: a review," in Aromatic and Medicinal Plants-Back to Nature, H. El-Shemy, Ed., https://www. intechopen.com/books/aromatic-and-medicinal-plants-backto-nature/biological-properties-of-essential-oils-from-the-piperspecies-of-brazil-a-review.

[2] L. O. Regasini, F. Cotinguiba, G. D. Passerini et al., "Trypanocidal activity of Piper arboreum and Piper tuberculatum (Piperaceae)," Revista Brasileira de Farmacognosia, vol. 19, no. 1, pp. 199-203, 2009.

[3] M. M. Azevedo, C. A. Almeida, F. C. Chaves et al., "Effects of 7-hydroxycalamenene isolated from Croton cajucara essential oil on growth, lipid content and ultrastructural aspects of Rhizopus oryzae," Planta Medica, vol. 80, no. 7, pp. 550-556, 2014.

[4] O. R. Gottlieb and M. T. Magalhães, "Modified distillation trap," Chemist Analyst, vol. 49, no. 4, p. 114, 1960.

[5] R. P. Adams, Identification of Essential Oil Components by Gas Chromatography/Mass Spectrometry, Carol Stream: Allured Publishing Corporation, Miami, FL, USA, 4th edition, 2007.

[6] Clinical and Laboratory Standards Institute (CLSI), Reference Method for Broth Dilution Antifungal Susceptibility Testing of Filamentous Fungi; Approved Standard M38, Clinical and Laboratory Standards Institute, Wayne, PA, USA, 2002.

[7] R. Singh, M. R. Shivaprakash, and A. Chakrabarti, "Biofilm formation by zygomycetes: quantification, structure and matrix composition," Microbiology, vol. 157, no. 9, pp. 2611-2618, 2011.

[8] K. A. Franca Rodrigues, L. V. Amorim, C. N. Dias, D. F. C. Moraes, S. M. P. Carneiro, and F. A. Amorim Carvalho, "Syzygium cumini (L.) Skeels essential oil and its major constituent $\alpha$-pinene exhibit anti-Leishmania activity through immunomodulation in vitro," Journal of Ethnopharmacology, vol. 160, pp. 32-40, 2015.

[9] M. Buroker-Kilgore and K. K. Wang, "A coomassie brilliant blue G-250-based colorimetric assay for measuring activity of calpain and other proteases," Analytical Biochemistry, vol. 208, no. 2, pp. 387-392, 1993.

[10] A. Calvin, O. Potterat, J. L. Wolfender, K. Hostettmann, and W. Dyatmyko, "Use of On-flow LC/1H NMR for the study of an antioxidant fraction from Orophea enneandra and isolation of a polyacetylene, lignans, and a tocopherol derivative," Journal of Natural Products, vol. 61, no. 12, pp. 1497-1501, 1998.

[11] M. M. B. Azevedo, F. C. M. Chaves, C. A. Almeida et al., "Antioxidant and antimicrobial activities of 7-hydroxycalamenene-rich essential oils from Croton cajucara Benth," Molecules, vol. 18, no. 1, pp. 1128-1137, 2013.

[12] S. O. Oyedemi, A. I. Okoh, L. V. Mabinya, G. Pirochenva, and A. J. Afolayan, "The proposed mechanism of bactericidal action of eugenol, $\propto$-terpineol and g-terpinene against Listeria monocytogenes, Streptococcus pyogenes, Proteus vulgaris and Escherichia coli," African Journal of Biotechnology, vol. 8, no. 7, 2009.

[13] A. C. R. Silva, P. M. Lopes, M. M. B. Azevedo, D. C. M. Costa, C. S. Alviano, and D. S. Alviano, "Biological activities of a-pinene and $\beta$-pinene enantiomers," Molecules, vol. 17, no. 6, pp. 6305-6316, 2012. 
[14] D. C. M. Costa, A. B. Vermelho, C. A. Almeida et al., "Inhibitory effect of linalool-rich essential oil from Lippia alba on the peptidase and keratinase activities of dermatophytes," Journal of Enzyme Inhibition and Medicinal Chemistry, vol. 29, no. 1, pp. 12-17, 2014.

[15] W. C. Silva, J. R. de Souza Martins, H. E. M. de Souza et al., "Toxicity of Piper aduncum L. (Piperales: Piperaceae) from the Amazon Forest for the cattle tick Rhipicephalus (Boophilus) microplus (Acari: Ixodidae)," Veterinary Parasitology, vol. 164, no. 2-4, pp. 267-274, 2009.

[16] R. R. P. de Almeida, R. N. P. Souto, C. M. Bastos, M. H. L. da Silva, and J. G. S. Maia, "Chemical variation in Piper aduncum and biological properties of its dillapiole-rich essential oil," Chemistry and Biodiversity, vol. 6, no. 9, pp. 1427-1434, 2009.

[17] R. N. P. Souto, A. Y. Harada, E. H. A. Andrade, and J. G. S. Maia, "Insecticidal activity of Piper essential oils from the Amazon against the fire ant Solenopsis saevissima (Smith) (Hymenoptera: Formicidae)," Neotropical Entomology, vol. 41, pp. 510-517, 2012.

[18] R. G. Ferreira, M. C. Monteiro, J. K. R. da Silva, and J. G. S. Maia, "Antifungal action of the dillapiole-rich oil of Piper aduncum against dermatomycoses caused by filamentous fungi," British Journal of Medicine and Medical Research, vol. 15, pp. 1-10, 2016.

[19] L. Monzote, M. García, A. M. Montalvo, R. Scull, and M. Miranda, "Chemistry, cytotoxicity and antileishmanial activity of the essential oil from Piper auritum," Memã $\tilde{a}^{3}$ rias Do Instituto Oswaldo Cruz, vol. 105, no. 2, pp. 168-173, 2010.

[20] J. K. R. da Silva, N. N. Silva, J. F. S. Santana, E. H. A. Andrade, J. G. S. Maia, and W. N. Setzer, "Phenylpropanoid-rich essential oils of Piper species from the Amazon and their antifungal and anti-cholinesterase activities," Natural Product Communications, vol. 11, pp. 1907-1911, 2016.

[21] J. K. da Silva, R. da Trindade, N. S. Alves, P. L. Figueiredo, J. G. S. Maia, and W. N. Setzer, "Essential oils from neotropical Piper species and their biological activities," International Journal of Molecular Sciences, vol. 18, no. 12, p. $2571,2017$.

[22] A. Sartoratto, A. L. M. Machado, C. Delarmelina et al., "Composition and antimicrobial activity of essential oils from aromatic plants used in Brazil," Brazilian Journal of Microbiology, vol. 35, no. 4, pp. 275-280, 2004.

[23] F. Nazzaro, F. Fratianni, R. Coppola, and V. D. Feo, "Essential oils and antifungal activity," Pharmaceuticals, vol. 10, no. 4, p. 86, 2017.

[24] A. L. S. D. Santos, "Aspartic proteases of human pathogenic fungi are prospective targets for the generation of novel and effective antifungal inhibitors," Current Enzyme Inhibition, vol. 7, no. 2, pp. 96-118, 2011.

[25] G. Ruberto and M. T. Baratta, "Antioxidant activity of selected essential oil components in two lipid model systems," Food Chemistry, vol. 69, no. 2, pp. 167-174, 2000. 


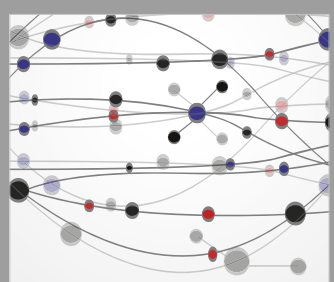

The Scientific World Journal
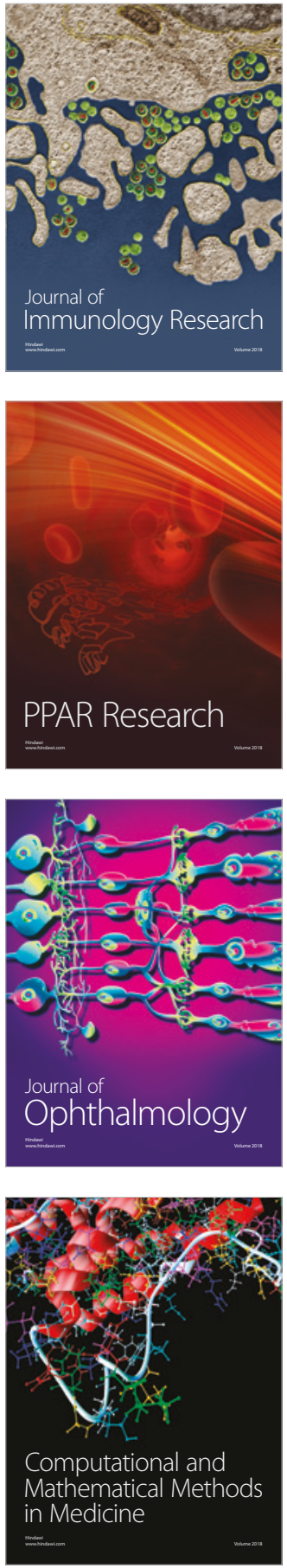

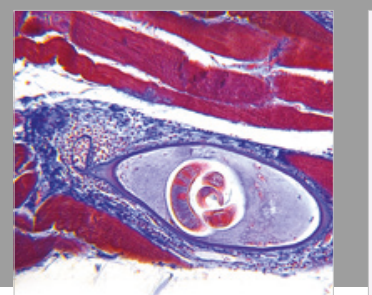

Gastroenterology Research and Practice

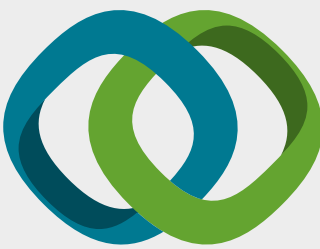

\section{Hindawi}

Submit your manuscripts at

www.hindawi.com
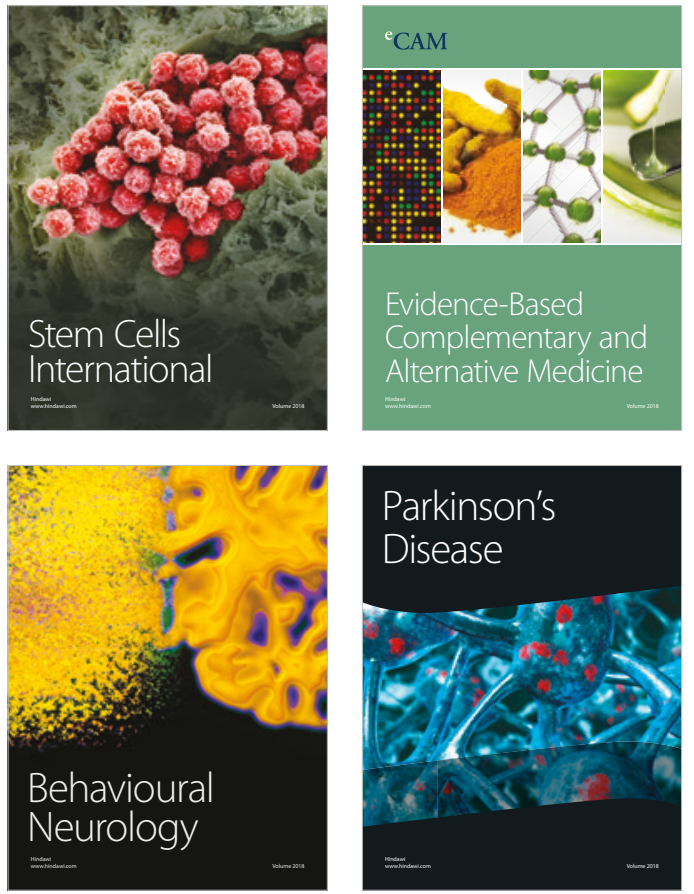

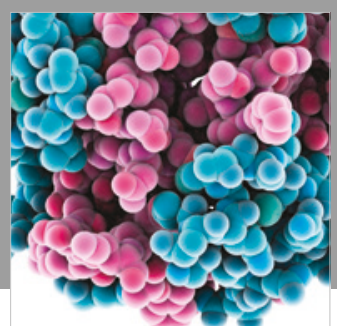

ournal of

Diabetes Research

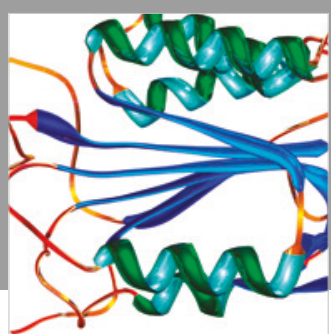

Disease Markers
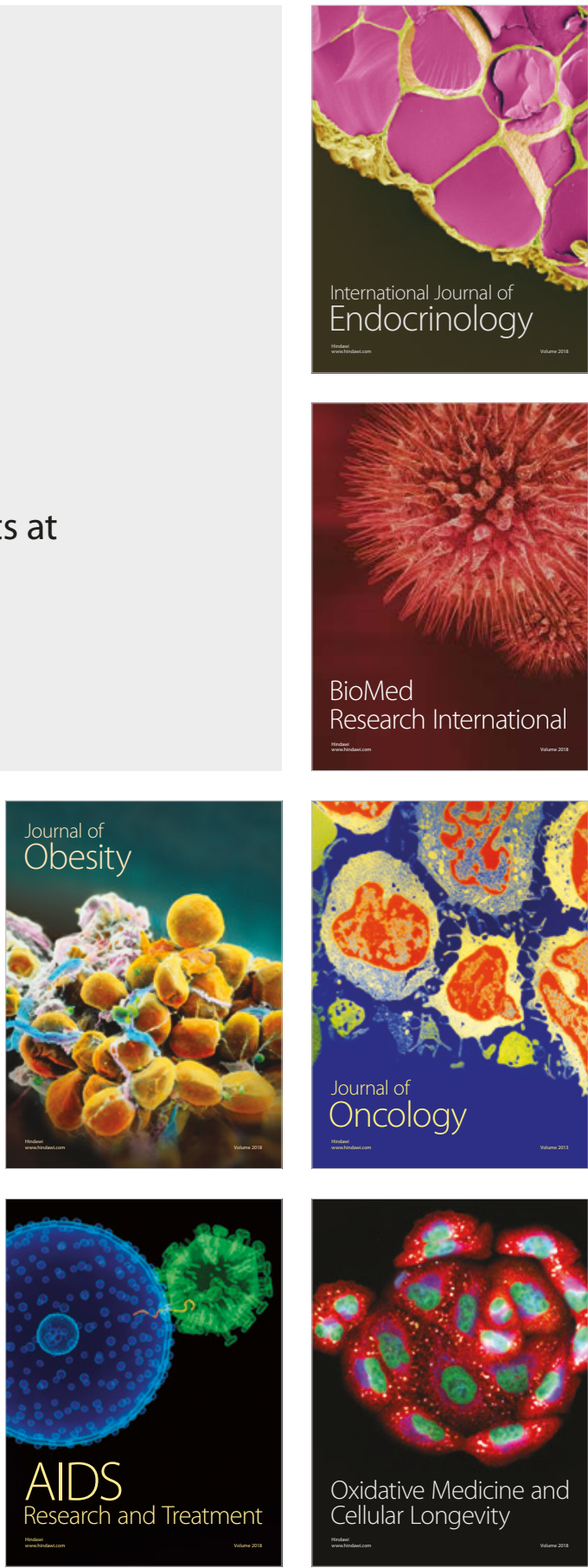